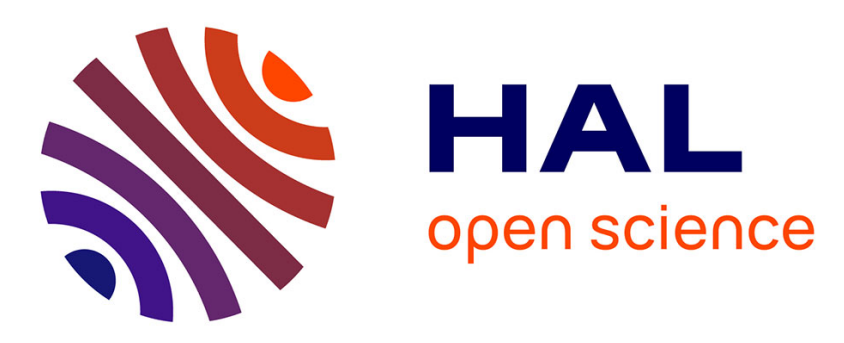

\title{
Effect of ligand structure on the Cu-II-R OMRP dormant species and its consequences for catalytic radical termination in ATRP
}

Thomas G. Ribelli, S. M. Wahidur Rahaman, Jean-Claude Daran, Pawel Krys, K. Matyjaszewski, Rinaldo Poli

\section{To cite this version:}

Thomas G. Ribelli, S. M. Wahidur Rahaman, Jean-Claude Daran, Pawel Krys, K. Matyjaszewski, et al.. Effect of ligand structure on the Cu-II-R OMRP dormant species and its consequences for catalytic radical termination in ATRP. Macromolecules, 2016, 49 (20), pp.7749-7757. 10.1021/acs.macromol.6b01334 . hal-01929758

\section{HAL Id: hal-01929758 \\ https://hal.science/hal-01929758}

Submitted on 1 Mar 2021

HAL is a multi-disciplinary open access archive for the deposit and dissemination of scientific research documents, whether they are published or not. The documents may come from teaching and research institutions in France or abroad, or from public or private research centers.
L'archive ouverte pluridisciplinaire HAL, est destinée au dépôt et à la diffusion de documents scientifiques de niveau recherche, publiés ou non, émanant des établissements d'enseignement et de recherche français ou étrangers, des laboratoires publics ou privés. 


\title{
Effect of Ligand Structure on the $\mathrm{Cu}^{\mathrm{II}}-\mathrm{R}$ OMRP Dormant Species and its Consequences for Catalytic Radical Termination in ATRP
}

Thomas G. Ribelli, ${ }^{a}$ S.M. Wahidur Rahaman, ${ }^{\mathrm{b}}$ Jean-Claude Daran, ${ }^{\mathrm{b}}$ Pawel Krys, ${ }^{\mathrm{a}}$ Krzysztof Matyjaszewski, ${ }^{\text {*a }}$ Rinaldo Poli*b,c

a Department of Chemistry, Carnegie Mellon University, 4400 Fifth Avenue, Pittsburgh, Pennsylvania 15213, USA.

b CNRS, LCC (Laboratoire de Chimie de Coordination), Université de Toulouse, UPS, INPT, 205 Route de Narbonne, BP 44099, F-31077, Toulouse Cedex 4, France.

c Institut Universitaire de France, 1, rue Descartes, 75231 Paris Cedex 05, France.

\begin{abstract}
The kinetics and mechanism of Catalytic Radical Termination (CRT) of $n$-butyl acrylate $(\mathrm{BA})$ in $\mathrm{MeCN}$ in the presence of $\mathrm{Cu}$ complexes with tridentate and tetradentate ligands was investigated both theoretically and experimentally. The tetradentate TPMA, TPMA*1, TPMA*2, TPMA*3 and the newly synthesized tridentate N-propyl-N,N-bis(4-methoxy-3,5-dimethylpyrid-2-ylmethtyl)amine (BPMA*Pr) as well as tridentate $\mathrm{BPMA}^{\mathrm{Me}}$ were used as ligands. $\mathrm{L} / \mathrm{Cu}^{\mathrm{II}} \mathrm{X}_{2}(\mathrm{X}=\mathrm{Cl}$ or OTf $)$ complexes were characterized by cyclic voltammetry (CV), UV-Vis-NIR and X-ray diffraction. Polymerization of $n$-butyl acrylate (BA) initiated by azobisisobutylnitrile (AIBN) $\mathrm{MeCN}$ in the presence of a $\mathrm{L} / \mathrm{Cu}^{\mathrm{I}}$ complex showed higher rates of CRT for more reducing $\mathrm{L} / \mathrm{Cu}^{\mathrm{I}}$ complexes. The ligand denticity (tri- vs. tetradentate) had a minor effect on the relative polymerization kinetics but affected the molecular weights in a way specific for ligand denticity. Quantification of the apparent CRT rate coefficients, $k_{C R T}^{a p p}$, showed larger values for more reducing $\mathrm{L} / \mathrm{Cu}^{\mathrm{I}}$ complexes, which correlated with
\end{abstract}


the $\mathrm{L} / \mathrm{Cu}^{\mathrm{II}}-\mathrm{R}\left(\mathrm{R}=\mathrm{CH}\left(\mathrm{CH}_{3}\right)\left(\mathrm{COOCH}_{3}\right)\right)$ bond strength, according to DFT calculations. The bond strength is mostly affected by the complex reducing power and to a lesser degree by the ligand denticity. Analysis of kinetics and molecular weights for different systems indicates that, depending on the ligand nature, the ratedetermining step of CRT may be either the radical addition to $\mathrm{L} / \mathrm{Cu}^{\mathrm{I}}$ to form the $\mathrm{L} / \mathrm{Cu}^{\mathrm{II}}$ $\mathrm{R}$ species or the reaction of the latter species with a second radical.

\section{Introduction}

Reversible deactivation radical polymerization (RDRP) has changed the scope of polymer science over the past two decades. At the heart of all RDRP methods is the concomitant growth of all chains through a reversible deactivation equilibrium between propagating radical and dormant species with retention of chain-end functionality. In atom transfer radical polymerization (ATRP), chain-end functionality of the dormant species is usually an alkyl halide $\left(\mathrm{P}_{n}-\mathrm{X}\right)$. Through a reversible redox process with a transition metal, most commonly copper, polymer chain ends are repetitively activated by the reduced complex, e. $g$. by $\mathrm{Cu}^{1} / \mathrm{L}$, to form the propagating radicals which are quickly deactivated by the oxidized complex, e.g. $\mathrm{X}-\mathrm{Cu}^{\mathrm{II}} / \mathrm{L}$. The equilibrium $\mathrm{L} / \mathrm{Cu}^{\mathrm{I}}+\mathrm{RX} \rightleftharpoons \mathrm{L} / \mathrm{Cu}^{\mathrm{II}}-\mathrm{X}+\mathrm{R}^{\bullet}$ is characterized by the equilibrium constant KATRP, which corresponds to the $\mathrm{k}_{\mathrm{a}} / \mathrm{kd}_{\mathrm{d}}$ ratio (Scheme 1$) .{ }^{1}$ Several parameters, including solvent, temperature, pressure, alkyl halide chain-end and ligand, affect the value of $\mathrm{K}_{\mathrm{ATRP}}{ }^{2-10}$

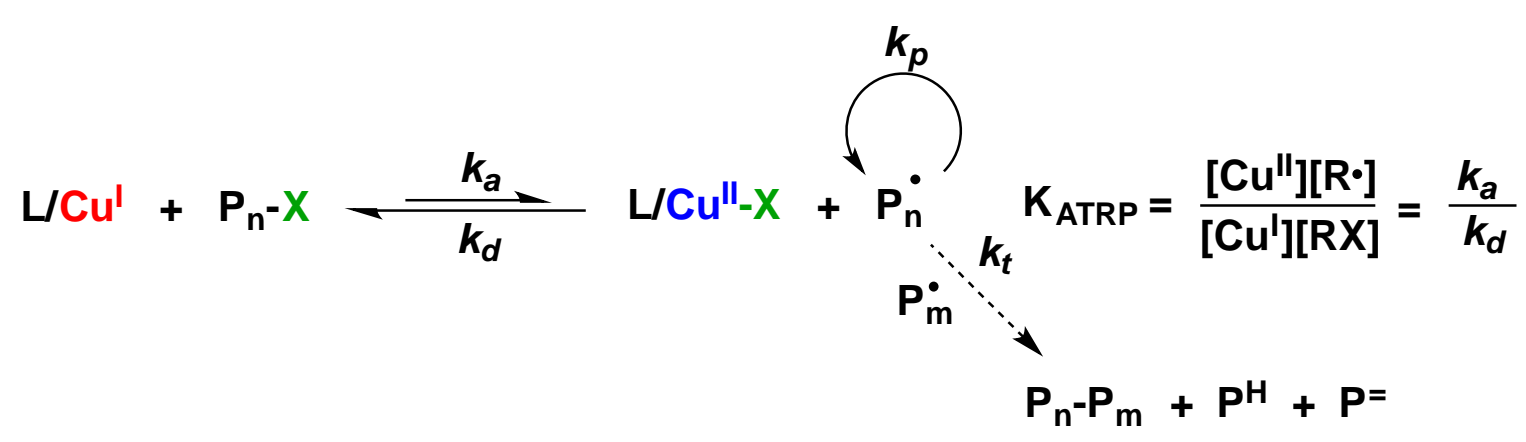


Scheme 1. Mechanism of normal ATRP showing conventional radical termination by combination or disproportionation

In order to polymerize less active monomers with higher R-X bond dissociation energies, complexes with larger values of $\mathrm{K}_{\text {ATRP }}$ should be used. This can be accomplished through appropriate ligand design. Over the past 20 years, a wide array of ligands has been synthesized which allow KatRP to be varied over 10 orders of magnitude. A linear correlation between redox potential, $\mathrm{E}_{1 / 2}$, and $\mathrm{K}_{\mathrm{ATRP}}$ is wellestablished. ${ }^{11}$ This understanding has allowed for the development of the most active ATRP catalyst to date, TPMA*3, which efficiently polymerized acrylates utilizing only $5 \mathrm{ppm}$ of $\mathrm{Cu}$ in ICAR ATRP. ${ }^{12}$ Figure 1 shows examples of four ligands that form very active ATRP catalysts with respective values of $k_{a}$ in parenthesis. They can be applied to various low ppm $\mathrm{Cu}$ ATRP systems. ${ }^{11,12}$
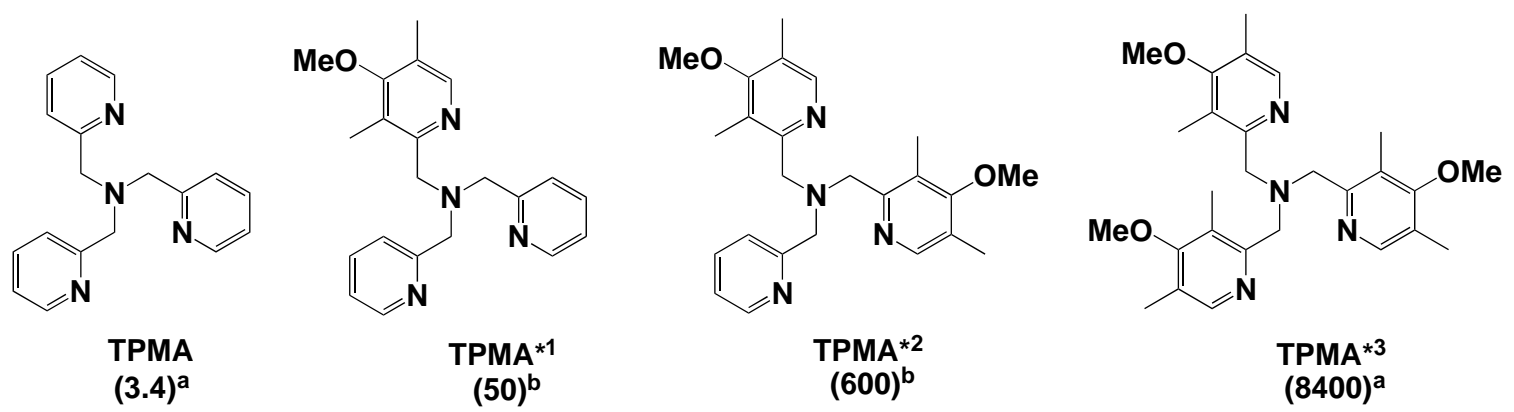

More Reducing

Figure 1. TPMA-based ligands that form very active ATRP catalysts when complexed to $\mathrm{Cu}$. Activity (larger KatRP and $\mathrm{ka}$ ) increases from left to right correlating to a more negative reduction potential, $\mathrm{E}_{1 / 2}$. Values in parenthesis are the activation rate coefficients, $\mathrm{k}_{\mathrm{a}}$, in $\mathrm{M}^{-1} \mathrm{~s}^{-1}$ for methyl 2-bromopropionate ( $\mathrm{MBrP}$ ) either a) measured in $\mathrm{MeCN}$ at $25^{\circ} \mathrm{C}^{9,12}$ or b) estimated from previously published electrochemical data. ${ }^{11}$

While highly active $\mathrm{Cu}^{\mathrm{I}}$ catalysts permitted polymerization of a large range of monomers, they can also react with propagating radicals to form $\mathrm{L} / \mathrm{Cu}^{\mathrm{II}}-\mathrm{R}$ species ${ }^{13-}$ 
14, akin to organometallic meditated radical polymerization (OMRP). ${ }^{15-17}$ The resulting $\mathrm{L} / \mathrm{Cu}^{\mathrm{II}}-\mathrm{R}$ dormant species can terminate through catalytic radical termination (CRT), especially in the polymerization of acrylates. ${ }^{18-20}$ Initially, the $\mathrm{dNbpy} 2 / \mathrm{Cu}^{\mathrm{I}}$ complex was shown to retard the rate of free radical polymerization (FRP) of acrylates. ${ }^{20}$ Later, it was reported that the FRP of methyl acrylate in the presence of the most active $\mathrm{TPMA}^{* 3} / \mathrm{Cu}^{\mathrm{I}}$ complex required 30 hours to reach $\sim 75 \%$ conversion, while in the absence of the $\mathrm{Cu}^{\mathrm{I}}$ complex the same conversion was reached in $\sim 30$ minutes. ${ }^{19}$ This retardation was attributed to $\mathrm{Cu}^{\mathrm{I}}$-promoted CRT, which has since been shown to be the dominant radical termination mechanism in acrylate ATRP systems. ${ }^{21-22}$

$$
\frac{\text { Rate }_{t, C u}}{\text { Rate }_{t, R}}=\frac{k_{t, C u(I I)}\left[L / C u^{I}\right][R \cdot]}{k_{t, R}[R \cdot]^{2}}=\frac{k_{t, C u(I I)}\left[L / C u^{I}\right]}{k_{t, R}[R \cdot]}
$$

Using equation 1, one can calculate the ratio of chains terminated via CRT to those terminated by conventional radical termination. This can be illustrated by analysis of two systems, a traditional ATRP and a low ppm ATRP, using the following parameters: $\left[\mathrm{R}^{*}\right]=1 \times 10^{-8} \mathrm{M} ; \mathrm{k}_{\mathrm{tR}}=3 \times 10^{8} \mathrm{M}^{-1} \mathrm{~s}^{-1} 23 ; k_{t, C u(I I)}=4 \times 10^{4} \mathrm{M}^{-1} \mathrm{~s}^{-118}$. Thus, in traditional ATRP where $\left[\mathrm{Cu}^{\mathrm{I}}\right]=5.5 \times 10^{-3} \mathrm{M}(1000 \mathrm{ppm}$ vs monomer $)$, CRT should account for $98.7 \%$ of total termination. However, even in the presence of $100 \mathrm{ppm}$ of $\mathrm{Cu}^{\mathrm{I}}$, CRT should still account for $88 \%$ of terminated chains. Therefore, due to the high contribution of CRT in the ATRP of acrylates, it is important to understand this unwanted side reaction in order to learn how to suppress it or decrease its importance.

As shown in Scheme 2, various mechanisms may be conceived for CRT. The organometallic species, $\mathrm{L} / \mathrm{Cu}^{\mathrm{II}}-\mathrm{R}$, were proposed to be involved in the unimolecular $\beta$-H elimination ${ }^{19}$ (a) and in the reaction with another radical to form a $\mathrm{L} / \mathrm{Cu}^{\mathrm{IIII}}-\mathrm{R}_{2}$ species, followed by reductive elimination ${ }^{24}(d)$. Other possibilities include direct $\beta$ $\mathrm{H}$ abstraction from the $\mathrm{L} / \mathrm{Cu}^{\mathrm{II}}-\mathrm{R}$ dormant species (b) or direct attack of the metal- 
bonded $\mathrm{C}$ atom in $\mathrm{L} / \mathrm{Cu}^{\mathrm{II}}-\mathrm{R}$ (c) by a propagating radical. While routes (a) and (b) lead to the radical disproportionation products, routes (c) and (d) lead to radical coupling. The recent DFT study for the $\mathrm{Cu} / \mathrm{TPMA}$ system suggest that $\beta$-H elimination pathway (a), leading to $\mathrm{L} / \mathrm{Cu}^{\mathrm{II}}-\mathrm{H}$ and olefin, has an unrealistically high activation energy and its contribution should be neglected. ${ }^{25}$ Therefore pathways (b-d) should be responsible for CRT process and their contributions may depend on reaction conditions and ligand structure.

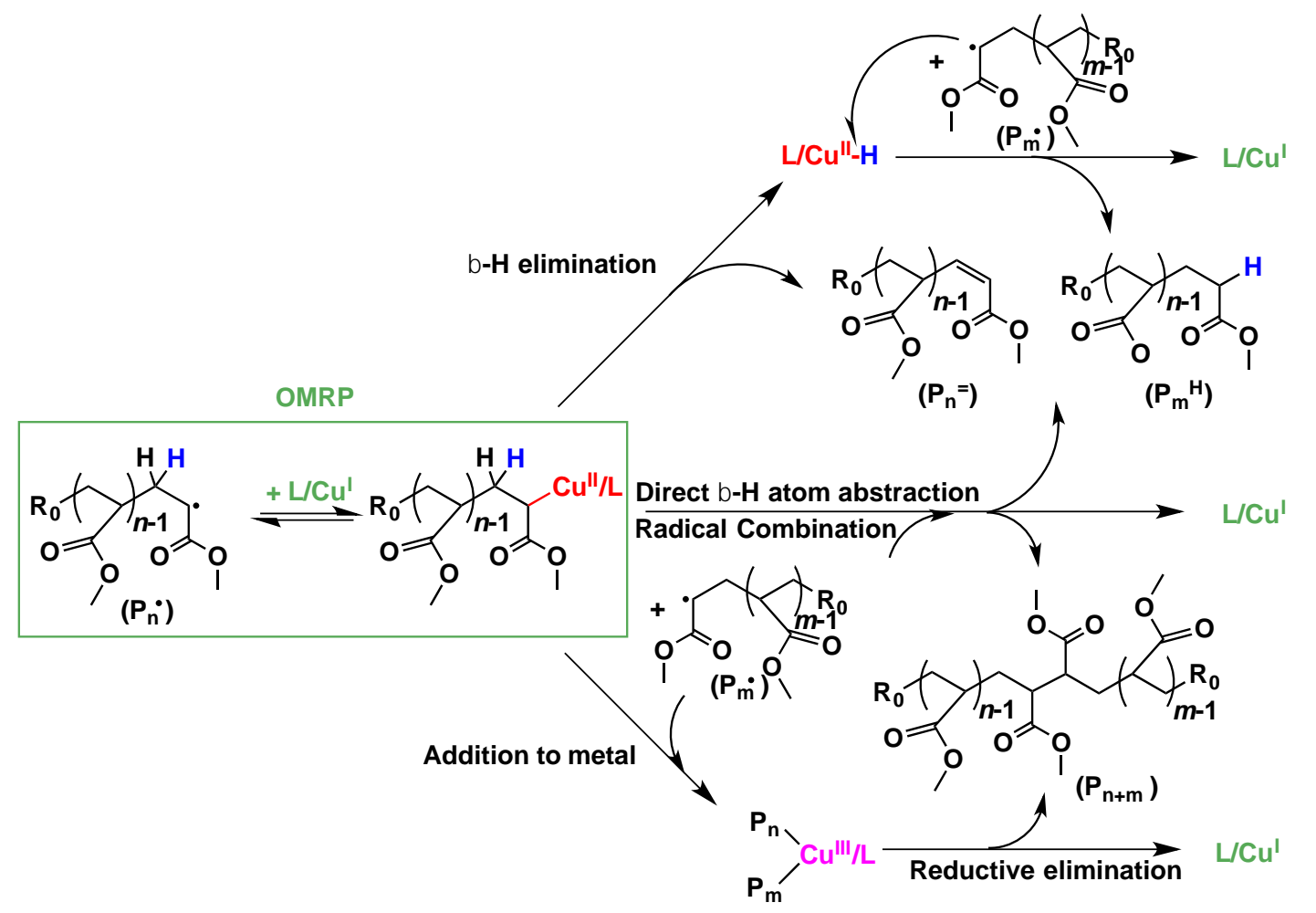

Scheme 2. Possible mechanisms of Cu-mediated CRT involving unimolecular reaction (route a) and bimolecular reactions (routes $\mathrm{b}-\mathrm{d}$ ), all proceeding through the $\mathrm{L} / \mathrm{Cu}^{\mathrm{II}}-\mathrm{R}$ species.

Typical OMRP systems operating via a reversible deactivation mechanism undergo a radical addition to a metal in a low oxidation state, $\mathrm{M}^{\mathrm{n}}$, resulting in an oxidized organometallic complex, $\mathrm{M}^{\mathrm{n}+1}-\mathrm{R}^{26-27}$ In order to maintain control over the polymerization, the equilibrium should be shifted to the side of dormant species, as shown in Scheme 3 (left). The metal-carbon bond strength defines the value of KomRP and is greatly affected by the choice of ligand, ${ }^{28}$ solvent, and nature of the radical. ${ }^{29}$ 
While cobalt based systems have been the most extensively studied and successfully applied in OMRP, copper-based systems have seen no success in OMRP. This could be attributed to the high reactivity of the $\mathrm{L} / \mathrm{Cu}^{\mathrm{II}}-\mathrm{R}$ dormant species and its ability to undergo catalytic radical termination (CRT).

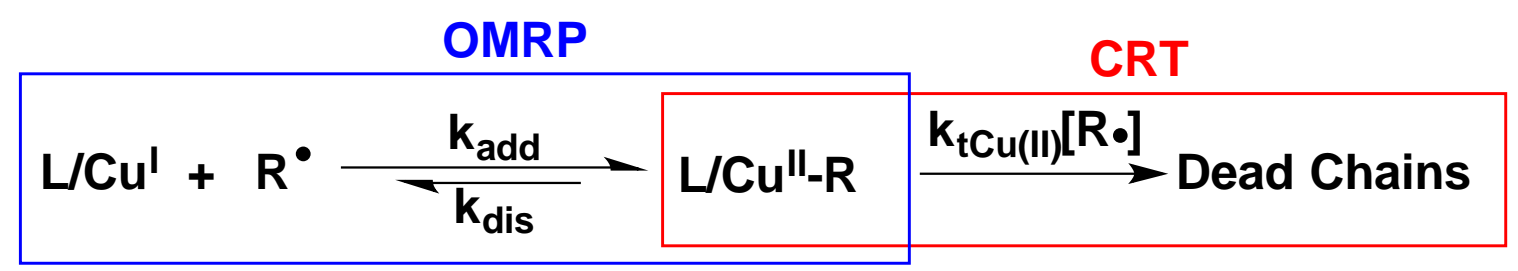

Scheme 3. Mechanism of copper mediated OMRP operating under a reversible deactivation mechanism and the addition of catalytic radical termination (CRT) where a radical terminates with the $\mathrm{L} / \mathrm{Cu}^{\mathrm{II}}-\mathrm{R}$ dormant species with rate coefficient $\mathrm{k}_{\mathrm{tCu}(\mathrm{II})}$.

Many OMRP reactions are initiated by thermal decomposition of diazo initiators such as AIBN to generate radicals which are quickly trapped by $\mathrm{L} / \mathrm{M}^{\mathrm{n}}$ to form the $\mathrm{L} / \mathrm{M}^{\mathrm{n}+1}-\mathrm{R}$ dormant species. This methodology has previously been carried out for copper-based systems where $\mathrm{L} / \mathrm{Cu}^{\mathrm{I}}$ acts as a radical trap to form the $\mathrm{L} / \mathrm{Cu}^{\mathrm{II}}-\mathrm{R}$ dormant species. ${ }^{19}$ Kinetic and molecular weight analyses showed significant CRT when using TPMA*3 as a ligand. While the mechanistic understanding of $\mathrm{Cu}$-mediated CRT is still inadequate, one can imagine the impact of ligand electronics and geometry on $\mathrm{L} / \mathrm{Cu}^{\mathrm{II}}-\mathrm{R}$ reactivity. Thus in the present study, various $\mathrm{L} / \mathrm{Cu}^{\mathrm{I}}$ complexes were used as OMRP trapping complexes in order to determine the effect that ligand structure has on CRT.

Both electronic and steric/geometrical properties of the ligand can significantly affect the $\mathrm{L} / \mathrm{Cu}^{\mathrm{II}}-\mathrm{R}$ bond strength as well as the possible CRT mechanism. Unfortunately, little is known about $\mathrm{L} / \mathrm{Cu}^{\mathrm{II}}-\mathrm{R}$ species ${ }^{30-34}$ due to their instability/high reactivity 35 although they have been discussed as possible intermediates in various systems. ${ }^{36-41}$ Thus, indirect methods such as those used in the present study must be conducted to better understand this elusive species. The results of experimental and computational studies presented here could pave the way for better understanding 
of catalytic cycles involving copper organometallic species not only in polymerizations but also in other systems.

\section{Results}

\section{Ligand and complex syntheses and characterization}
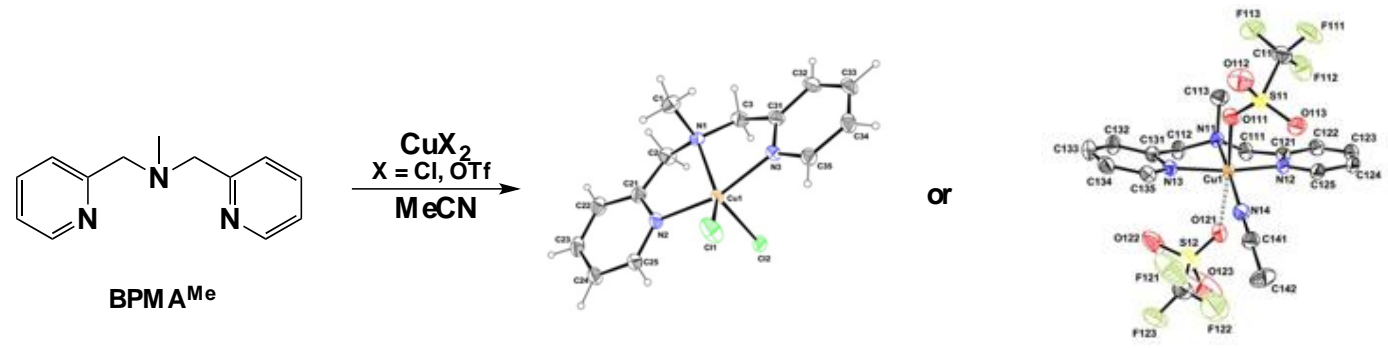

$\left[\mathrm{Cu}^{\prime \prime}\left(\mathrm{BPM} \mathrm{A}^{\mathrm{Me}}\right) \mathrm{Cl}_{2}\right] \quad(1) \quad\left[\mathrm{Cu}^{\prime \prime}\left(\mathrm{BPM} \mathrm{A}^{\mathrm{Me}}\right)(\mathrm{MeCN})(\mathrm{OTf})\right][\mathrm{OTf}] \quad$ (2)

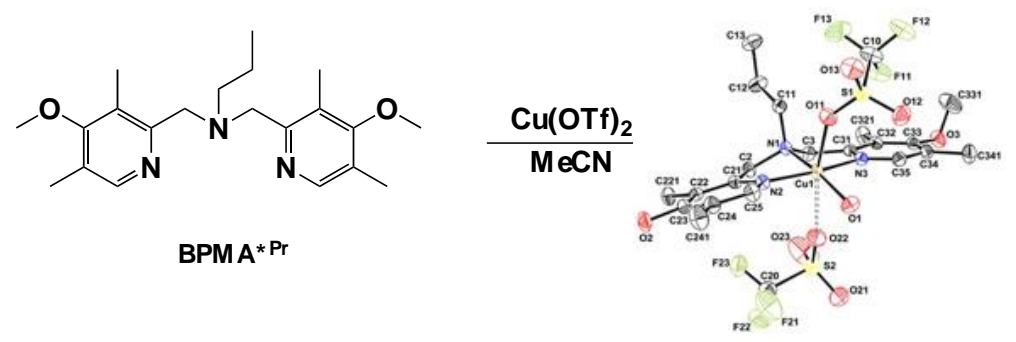

[Cu'l(BPM A* $\left.\left.{ }^{*}\right)\left(\mathrm{H}_{2} \mathrm{O}\right)(\mathrm{OTf})\right][\mathrm{OTf}] \quad(3)$

Scheme 4. Synthesis and X-ray structures of $\mathrm{Cu}^{\mathrm{II}}$ complexes with the BPMA ${ }^{\mathrm{Me}}$ and BPMA $^{* P r}$ ligands. The ligand $\mathrm{H}$ atoms in the structures of $\mathbf{2}$ and $\mathbf{3}$ have been omitted for clarity.

The $\mathrm{L} / \mathrm{Cu}^{\mathrm{I}}$ complexes used in the CRT studies were generated in situ from $\left[\mathrm{Cu}(\mathrm{MeCN})_{4}\right]\left[\mathrm{BF}_{4}\right]$ and the ligands from the tetradentate TMPA-based family (TPMA, TPMA $^{* 1}$, TPMA $^{* 2}$, TPMA*3, see Figure 1), ${ }^{11-12}$ the tridentate BPMA ${ }^{\text {Me42 }}$ and the new BPMA $^{* \operatorname{Pr}}$ (see Scheme 4 for ligand structure). BPMA ${ }^{\mathrm{Me}} 42$ and the TPMA-based ligands ${ }^{11-12}$ were prepared according to previously published procedures while $\mathrm{BPMA}^{* \mathrm{Pr}}$ is reported for the first time here. The tridentate ligands have also been used to generate a few well-defined $\mathrm{Cu}^{\mathrm{II}}$ derivatives (see Scheme 4) although these were crystallized for electrochemical characterization and to ensure correct ligand 
synthesis and are otherwise not used in this study. Complex $\mathbf{1}$ has already been reported ${ }^{43}$ but its X-ray structure has now been obtained with greater precision,

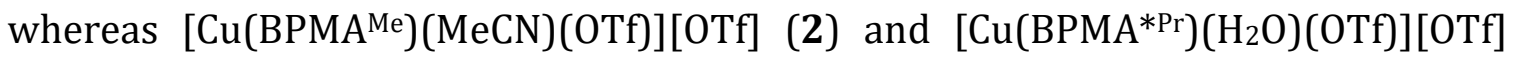
(3) are reported here for the first time. Synthetic details for the ligands and $\mathrm{Cu}^{\mathrm{II}}$ complexes as well as a full discussion of these structures as well as absorption spectra are included in the Supporting Information.

Cyclic Voltammetry (CV). As shown in Figure S4, 2 has a quasi-reversible reduction wave with $\mathrm{E}_{1 / 2}=+113 \mathrm{mV}$ vs. SCE. Substituting the pyridine rings with the electron donating methoxy and methyl groups, as in $\mathbf{3}$, causes a negative shift in the reduction potential, Ered $=0 \mathrm{mV}$ (Figure S5), consistent with previous results using the tetradentate TPMA ligand scaffold. The latter complex shows a wave with reduced intensity of the return oxidation peak even at higher scan rates when using a Pt-disk working electrode. However, when a glassy carbon electrode was used, a pseudo-symmetric reversible wave was obtained with $\mathrm{E}_{1 / 2}=+70 \mathrm{mV}$. Compound 1 (Figure S4) has a drastic negative shift in the half-wave potential $\left(E_{1 / 2}=-220 \mathrm{mV}\right.$ ) due to a more stable $\mathrm{Cu}^{\mathrm{II}}$ species because of the stronger coordination of the $\mathrm{Cl}^{-}$anions compared to weakly coordinating OTf anions. All electrochemical data for newly and previously synthesized complexes used in this report are presented in Table 1.

Table 1. Electrochemical data of copper complexes used in this study at $25^{\circ} \mathrm{C}$. All measurements were conducted in $\mathrm{MeCN}$ with $0.1 \mathrm{M}^{\mathrm{TBAPF}} 6$ as a supporting electrolyte at a scan rate of $100 \mathrm{mV} / \mathrm{s}$ with $\left[\mathrm{Cu}^{\mathrm{II}} \mathrm{X}_{2}\right]_{0}=1 \mathrm{mM}$. All potentials are vs. SCE.

\begin{tabular}{|cccccc|}
\hline Complex $^{\mathrm{a}}$ & $\mathrm{E}_{\text {red }}(\mathrm{mV})$ & $\mathrm{E}_{\text {ox }}(\mathrm{mV})$ & $\mathrm{E}_{1 / 2}(\mathrm{mV})$ & $\Delta \mathrm{E}_{\mathrm{p}}(\mathrm{mV})$ & ref \\
\hline $\mathbf{1}$ & -300 & -145 & -220 & 155 & This work \\
\hline $\mathbf{2}$ & 61 & 174 & 174 & 113 & This work \\
\hline $\mathbf{3}$ & 0 & 140 & 70 & 140 & This work \\
\hline$\left[\mathrm{Cu}\left(\mathrm{TPMA}^{2}\right)\right][\mathrm{OTf}]_{2}$ & -25 & 69 & 22 & 94 & 44 \\
\hline$\left[\mathrm{Cu}\left(\mathrm{TPMA}^{*}\right)\right][\mathrm{OTf}]_{2}$ & -130 & -12 & -69 & 118 & 44 \\
\hline$\left[\mathrm{Cu}\left(\mathrm{TPMA}^{* 2}\right)\right][\mathrm{OTf}]_{2}$ & -206 & -60 & -133 & 146 & 44 \\
\hline$\left[\mathrm{Cu}\left(\mathrm{TPMA}^{* 3}\right)\right][\mathrm{OTf}]_{2}$ & -255 & -100 & -177 & 155 & 44 \\
\hline
\end{tabular}




\section{Polymerization Studies}

To experimentally probe the effect of ligand denticity and its electron donating power on $\mathrm{Cu}$-promoted $\mathrm{CRT}$, OMRP reactions mediated by various $\mathrm{L} / \mathrm{Cu}^{\mathrm{I}}$ complexes were conducted. Primary radicals were generated by thermal dissociation of azobisisobutyronitrile (AIBN). The propagating radical chains were then intercepted by the $\mathrm{L} / \mathrm{Cu}^{\mathrm{I}}$ complex $\left(\mathrm{L}=\mathrm{BPMA}^{\mathrm{Me}}, \mathrm{BPMA}^{* \mathrm{Pr}}\right.$, TPMA and $\left.\mathrm{TPMA}^{* \mathrm{n}} ; \mathrm{n}=1,2,3\right)$, promoting CRT. The monomer conversion and polymer molecular weights were analyzed in order to gain mechanistic insight into the CRT process.

OMRP reactions were first carried out at three different concentrations of TPMA/CuI. As shown in Figure 2A, after a short induction period, linear semilogarithmic monomer conversion plots were observed at all $\left[\mathrm{L} / \mathrm{Cu}^{\mathrm{I}}\right]_{0}$, indicating the establishment of a steady-state concentration of radicals. To reach monomer conversion of $\sim 25 \%$, it took 20,45, 120 and 145 minutes for $0,100,500,1000 \mathrm{ppm}$ of $\mathrm{Cu}^{\mathrm{I}} / \mathrm{TPMA}$. This is consistent with a higher concentration of dormant species and higher rate of CRT in the presence of greater amounts of $\mathrm{L} / \mathrm{Cu}^{\mathrm{I}}$, as previously reported. ${ }^{18}$ Figure $2 \mathrm{~B}$ shows that, in the absence of $\mathrm{L} / \mathrm{Cu}^{\mathrm{I}}$, the molecular weight decreases with conversion, consistent with FRP. Upon introduction of $\mathrm{Cu}^{\mathrm{I}}$ /TPMA to the system, the molecular weights decreased dramatically as compared to FRP. At $25 \%$ monomer conversion, FRP gave polymers with molecular weights of $\sim 1.5 \times 10^{6}$ while the reactions in the presence of $\mathrm{L} / \mathrm{Cu}^{\mathrm{I}}$ gave polymers with molecular weights $<5 \times 10^{5}$, indicating faster radical termination due to CRT. Interestingly, upon increasing the amount of $\mathrm{L} / \mathrm{Cu}^{\mathrm{I}}$ in the system, molecular weights only slightly decreased. At catalysts loadings of 100, 500 and $1000 \mathrm{ppm}$, the molecular weights were $4.7,3.7$, and $3.3 \times 10^{5}$ at $\sim 30 \%$ conversion, respectively. 

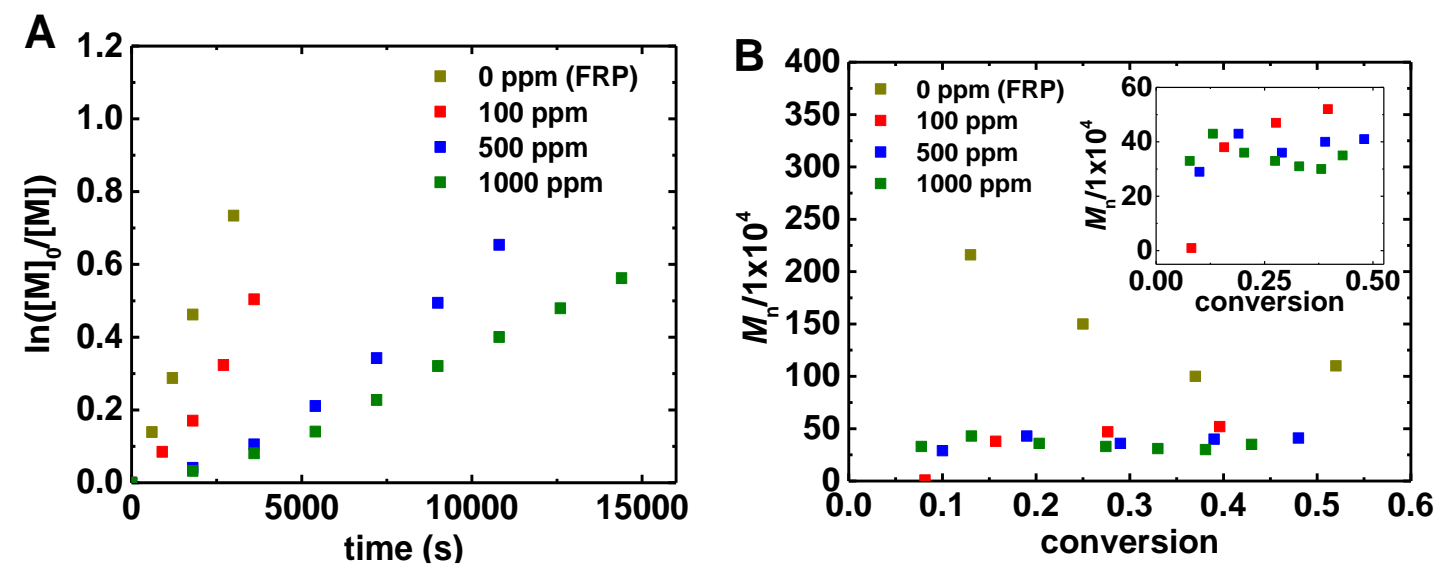

Figure 2. a) Kinetics and b) molecular weight data of the polymerization of n-butyl acrylate (BA) initiated by AIBN in the presence (OMRP) and absence (FRP) of TPMA $/ \mathrm{Cu}^{\mathrm{I}}$ at $60^{\circ} \mathrm{C}$. Initial molar ratios of reagents were [nBA]:[AIBN]:[TPMA]: $\left[\mathrm{Cu}^{\mathrm{I}}(\mathrm{MeCN}) 4\right]\left[\mathrm{BF}_{4}\right]=160: 0.2: 2 \mathrm{x}: \mathrm{x}(\mathrm{x}=0-0.16)$ at $60^{\circ} \mathrm{C}$ in $50 \% \mathrm{MeCN} ;[\mathrm{nBA}]_{0}=3.48 \mathrm{M}$; $100 \mathrm{ppm}=0.016$.

Next, the TPMA ${ }^{*_{n}}$ ligand family was employed using the same amount of $\mathrm{L} / \mathrm{Cu}^{\mathrm{I}}$ (500 ppm) to further assess the effect of reduction potential (Table 1) on the overall rate of $\mathrm{Cu}$-promoted $\mathrm{CRT}$. The overall rate of polymerization decreased progressively upon using more reducing $\mathrm{L} / \mathrm{Cu}^{\mathrm{I}}$ complexes, as shown in Figure 3A. Furthermore, using higher-activity catalysts, polymers with lower molecular weights were obtained. These two results show that CRT activity correlates with reducing power of the $\mathrm{L} / \mathrm{Cu}^{\mathrm{I}}$ complex.
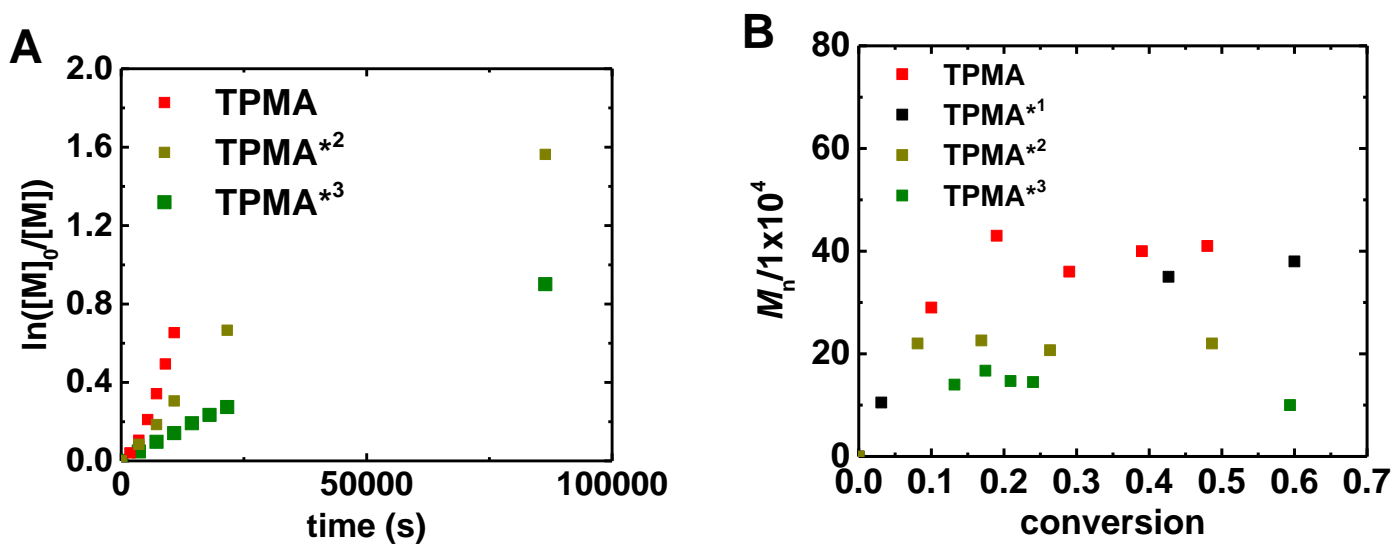
Figure 3. a) Kinetics and b) molecular weight data of $n$-butyl acrylate (BA) polymerization initiated by AIBN in the presence (OMRP) and absence (FRP) of $\mathrm{L} / \mathrm{Cu}^{\mathrm{I}}$ $\left(\mathrm{L}=\mathrm{TPMA}, \mathrm{TPMA}^{* 1}, \mathrm{TPMA}^{* 2}, \mathrm{TPMA}^{* 3}\right)$ at $60^{\circ} \mathrm{C}$. Initial molar ratios were $[\mathrm{BA}]:[\mathrm{AIBN}]:[\mathrm{L}]:\left[\mathrm{Cu}^{\mathrm{I}}(\mathrm{MeCN})_{4}\right]\left[\mathrm{BF}_{4}\right]=160: 0.2: 0.16: 0.08$ at $60^{\circ} \mathrm{C}$ in $50 \% \mathrm{MeCN} ;[\mathrm{BA}]_{0}$ $=3.48 \mathrm{M}$.

Finally, analogous reactions were conducted using the tridentate BPMA ligand scaffold to determine the effect of denticity on CRT. Using BPMA ${ }^{\mathrm{Me}} / \mathrm{Cu}^{\mathrm{I}}$ at a $1000 \mathrm{ppm}$ loading, a slow and gradual increase in the rate was observed during the first hour, indicating some interactions between radical and $\mathrm{BPMA}^{\mathrm{Me}} / \mathrm{Cu}^{\mathrm{I}}$, as shown in Figure $\mathrm{S7}$. The rate gradually increased over 60 minutes until the steady-state rate was the same as in FRP. Moreover, the molecular weights were lower than in FRP, indicating that this complex is mildly active in CRT.

The BPMA ${ }^{* P r} / \mathrm{Cu}^{\mathrm{I}}$ complex (reducing power similar to TPMA/Cu'), resulted in a much more pronounced decrease in the polymerization rate compared to $\mathrm{BPMA}^{\mathrm{Me}} / \mathrm{Cu}^{\mathrm{I}}$, as shown in Figure 4 . This complex also showed progressively decreasing rates upon increasing $\left[\mathrm{L} / \mathrm{Cu}^{\mathrm{I}}\right]_{0}$, similar to the TPMA system. However, a strong decrease in molecular weights was observed upon increasing [L/Cul] ${ }_{0}$ with $M_{\mathrm{n}}$ values of 1.3, 0.56 and $0.25 \times 10^{6}$ at $~ 30 \%$ conversion when using 100, 500 and 1000 ppm of $\mathrm{L} / \mathrm{Cu}^{\mathrm{I}}$, respectively. Interestingly, the kinetic data for $\mathrm{BPMA}^{* \mathrm{Pr}} / \mathrm{Cu}^{\mathrm{I}}$ was similar to those using TPMA ( $c f$. Figure 2), while molecular weight trends were quite different. This difference will be discussed later in the discussion section. Molecular weight analysis of all polymerization systems showed broad molecular weight distributions and little to no increase in molecular weight with conversion. This further indicates that the $\mathrm{L} / \mathrm{Cu}^{\mathrm{I}}$ complexes used in this study are inefficient OMRP mediators and primarily act as catalysts for CRT. 

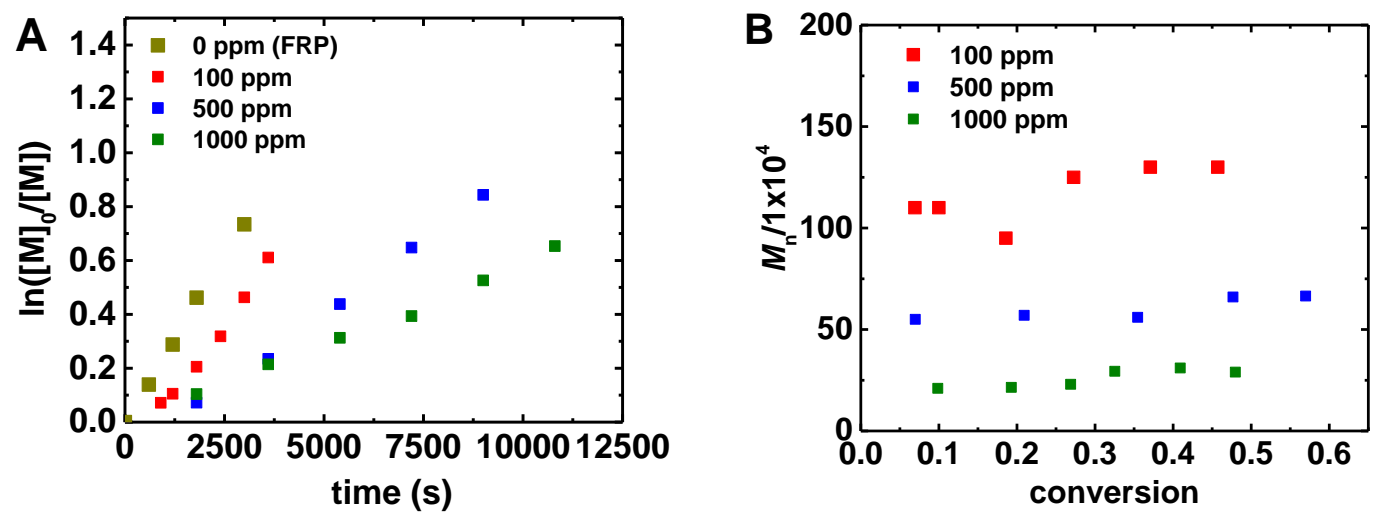

Figure 4. a) Kinetics and b) molecular weight data of n-butyl acrylate (BA) initiated by AIBN in the presence (OMRP) and absence (FRP) of $\mathrm{BPMA}^{* \mathrm{Pr}} / \mathrm{Cu}^{\mathrm{I}}$ at $60^{\circ} \mathrm{C}$. Initial molar ratios were $[\mathrm{nBA}]:[\mathrm{AIBN}]:\left[\mathrm{BPMA}^{* \mathrm{Pr}}\right]:\left[\mathrm{Cu}^{\mathrm{I}}(\mathrm{MeCN}) 4\right]\left[\mathrm{BF}_{4}\right]=160: 0.2: 2 \mathrm{x}: \mathrm{x}(\mathrm{x}=0-$ $0.16)$ at $60^{\circ} \mathrm{C}$ in $50 \% \mathrm{MeCN} ;[\mathrm{nBA}]_{0}=3.48 \mathrm{M} ; 100 \mathrm{ppm}=0.016$.

The apparent rate constants of polymerization and molecular weights as a function of the reduction potential of the $\mathrm{L} / \mathrm{Cu}^{\mathrm{II}}$ complex are illustrated in Figure 5. This plot shows that the rate of $\mathrm{CRT}$ increases for more reducing $\mathrm{L} / \mathrm{Cu}^{\mathrm{I}}$ complexes.

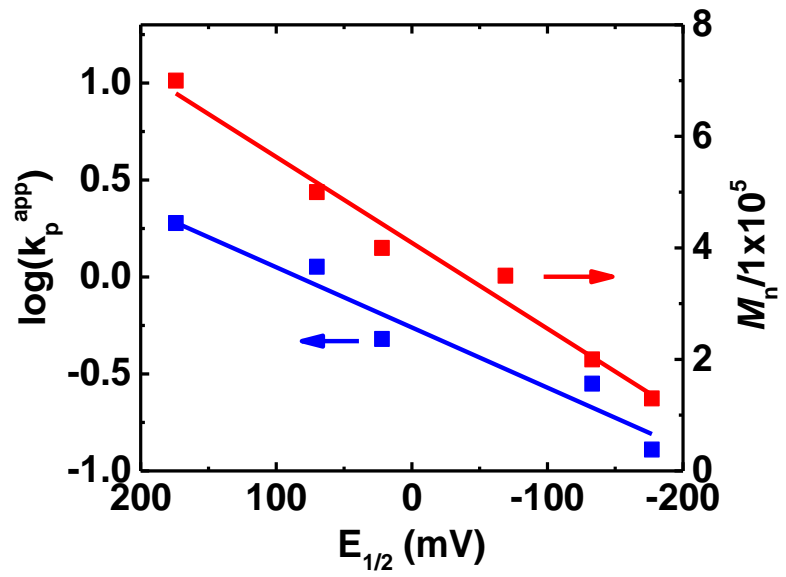

Figure 5. Relationship between measured values of $E_{1 / 2}$ and both molecular weights (red) and rate of polymerization (blue). All values are for reactions using $500 \mathrm{ppm}$ of $\mathrm{L} / \mathrm{Cu}^{\mathrm{I}}$. The molecular weights for $\mathrm{BPMA}^{\mathrm{Me}} / \mathrm{Cu}^{\mathrm{I}}$ were measured using $1000 \mathrm{ppm} \mathrm{L} / \mathrm{Cu}^{\mathrm{I}}$. 
The above kinetic investigations discussed above pointed towards radical trapping by $\mathrm{L} / \mathrm{Cu}^{\mathrm{I}}$ to yield a $\mathrm{L} / \mathrm{Cu}^{\mathrm{II}}$ organometallic intermediate. The question can be asked whether the CRT activity correlates with the $\mathrm{Cu}^{\mathrm{II}}-\mathrm{C}$ bond strength. Thus, the Bond Dissociation Free Energies (BDFE) for all $\mathrm{L} / \mathrm{Cu}^{\mathrm{II}}-\mathrm{R}$ species studied were estimated by DFT calculations. The ligands BPMAMe, TPMA, TPMA*1-3 were used for all systems except for BPMA ${ }^{* P r}$, where the Pr group was simplified to an electronically similar Me group, BPMA*Me. The calculations were carried out using BP86-D3 with the 6-311G(d,p) basis set for the light atoms $(\mathrm{O}, \mathrm{N}, \mathrm{C}, \mathrm{H})$ and the LANL2DZ(f) basis for $\mathrm{Cu}$. Additional thermal and solvation corrections (in MeCN solution) were applied (see computational details). This is the same level of theory used by us recently for the exploration of the [(TPMA)Cu$\left.{ }^{I I-H}\right]^{+}$formation by direct $\beta-\mathrm{H}$ atom transfer from a free radical. ${ }^{25}$

Since the experimental CRT studies were carried out in $\mathrm{MeCN}$, a stabilization of the $\mathrm{L} / \mathrm{Cu}^{\mathrm{I}}$ species by solvent coordination (Eq. 2), affecting the OMRP equilibrium, is possible. This was confirmed by X-ray structural study of the [Cu$(\mathrm{TPMA})(\mathrm{MeCN})]\left[\mathrm{BPh}_{4}\right]$ salt. ${ }^{45-46}$ The MeCN coordination stabilizes [CuI(TPMA)] ${ }^{+}$ by $2.4 \mathrm{kcal} / \mathrm{mol}$ at the used level of theory, suggesting that the $\mathrm{L} / \mathrm{Cu}^{\mathrm{I}}$ species should be coordinated by MeCN. The optimized geometry for the acetonitrile adduct $\left[\mathrm{Cu}^{\mathrm{I}}(\mathrm{TPMA})(\mathrm{MeCN})\right]^{+}$is in good agreement with the structure determined by X-ray (see Table S3).

$\left[\mathrm{Cu}^{\mathrm{I}}(\mathrm{L})\right]^{+}+\mathrm{MeCN} \rightleftharpoons\left[\mathrm{Cu}^{\mathrm{I}}(\mathrm{L})(\mathrm{MeCN})\right]^{+}$

In order to give these calculations quantitative merit, the activation of the $\mathrm{CH}_{3} \mathrm{CH}(\mathrm{Br}) \mathrm{COOCH}_{3} \mathrm{ATRP}$ initiator by the $\left[\mathrm{Cu}^{\mathrm{I}}(\mathrm{TPMA})\right]^{+}$system was investigated, because the KATRP of this equilibrium has been experimentally determined (KATRP = $3.2 \times 10^{-7} ; \Delta G_{\text {ATRP }}=8.8 \mathrm{kcal} / \mathrm{mol}$ ) in $\mathrm{MeCN}$ at $22^{\circ} \mathrm{C}^{4}$ The computed $\Delta G_{\text {ATRP }}$ values are 10.2 and $7.8 \mathrm{kcal} / \mathrm{mol}$ with (Eq 3) and without (Eq 4) $\mathrm{MeCN}$ coordination to $\mathrm{Cu}^{\mathrm{I}}$, respectively. Both values are in good agreement with the experimentally determined value of $8.8 \mathrm{kcal} / \mathrm{mol}$, confirming the suitability of this level of theory. 


$$
\begin{aligned}
& {\left[\mathrm{Cu}^{\mathrm{I}}(\mathrm{TPMA})(\mathrm{MeCN})\right]^{+}+\mathrm{R}-\mathrm{Br} \rightleftharpoons\left[\mathrm{Cu}{ }^{\mathrm{II}} \mathrm{Br}(\mathrm{TPMA})\right]^{+}+\mathrm{R} \bullet+\mathrm{MeCN}} \\
& {\left[\mathrm{Cu}^{\mathrm{I}}(\mathrm{TPMA})\right]^{+}+\mathrm{R}-\mathrm{Br} \rightleftharpoons\left[\mathrm{Cu}^{\mathrm{II}} \mathrm{Br}(\mathrm{TPMA})\right]^{+}+\mathrm{R} \cdot} \\
& \mathrm{R}=\mathrm{CH}\left(\mathrm{CH}_{3}\right) \mathrm{COOCH}_{3}
\end{aligned}
$$

Given the experimental and theoretical evidence of $\mathrm{MeCN}$ coordination to $\left[\mathrm{Cu}^{\mathrm{I}}(\mathrm{TPMA})\right]^{+}$, the free energy of $\mathrm{MeCN}$ addition $\left(\Delta \mathrm{G}_{\mathrm{MeCN}}\right)$ was also calculated for all other $\left[\mathrm{Cu}^{\mathrm{I}}(\mathrm{L})\right]^{+}$complexes (Eq. 2). The $\mathrm{Cu}^{\mathrm{II}}-\mathrm{R}\left(\mathrm{R}=\mathrm{CH}\left(\mathrm{CH}_{3}\right) \mathrm{COOCH}_{3}\right)$ bond dissociation free energy (BDFE, Eq. 5) was combined with the MeCN coordination to yield Eq 6 as the operating OMRP equilibrium. The results are shown in Table 2.

$$
\begin{aligned}
& {\left[\mathrm{Cu}^{\mathrm{I}}(\mathrm{L})\right]^{+}+\cdot \mathrm{R} \rightleftharpoons\left[\mathrm{Cu}^{\mathrm{II}} \mathrm{R}(\mathrm{L})\right]^{+}} \\
& {\left[\mathrm{Cu}^{\mathrm{I}}(\mathrm{L})(\mathrm{MeCN})\right]^{+}+\cdot \mathrm{R} \rightleftharpoons\left[\mathrm{Cu}^{\mathrm{II}} \mathrm{R}(\mathrm{L})\right]^{+}+\mathrm{MeCN}}
\end{aligned}
$$

Table 2. Calculated $\Delta G$ values (in $\mathrm{kcal} / \mathrm{mol}$ ) for processes related to the $\cdot \mathrm{CH}\left(\mathrm{CH}_{3}\right) \mathrm{COOCH}_{3}$ trapping by $\left[\mathrm{L} / \mathrm{Cu}^{\mathrm{I}}\right]^{+}$. The values are corrected for solvation in $\mathrm{MeCN}$.

\begin{tabular}{|c|c|c|c|}
\hline $\mathrm{L}$ & BDFE $^{\mathrm{a}}$ & $\Delta G_{\mathrm{MeCN}^{\mathrm{b}}}$ & $\Delta G_{\mathrm{OMRP}^{\mathrm{C}}}$ \\
\hline BPMA $^{\mathrm{Me}}$ & 14.1 & -4.9 & -9.2 \\
\hline BPMA $^{* \mathrm{Me}}$ & 16.1 & -5.3 & -10.8 \\
\hline TPMA $^{*}$ & 14.3 & -2.4 & -11.9 \\
\hline TPMA $^{* 1}$ & 15.1 & -2.1 & -13.0 \\
\hline TPMA $^{* 2}$ & 15.8 & -2.4 & -13.4 \\
\hline TPMA $^{* 3}$ & 17.6 & -2.9 & -14.7 \\
\hline
\end{tabular}

a $\Delta G$ associated to the reverse of Eq. 5 (bond dissociation). ${ }^{\mathrm{b}} \Delta G$ associated to Eq. 2. ${ }^{\mathrm{c}}$ $\Delta G$ associated to Eq. 6.

The values of BDFE for the TPMA ${ }^{*_{n}}$ series correlate well with the CRT activity, each substitution of a py by a py* donor resulting in a BDFE increase. This effect is electronic, not steric, because the increase of steric bulkiness upon py/py* 
modification would lead to bond weakening. The CRT activity correlates better with $\Delta G_{\text {OMRP }}$ than with BDFE. In fact, the $\left[\mathrm{Cu}^{\mathrm{I}}(\mathrm{L})\right]^{+}$stabilization by MeCN coordination is ca. twice stronger for tridentate BPMA and BPMA* systems than for the tetradentate TPMA $^{* \mathrm{n}}$ systems. In terms of correlation with $\mathrm{E}_{1 / 2}$, the experimentally measured 199 $\mathrm{mV}$ decrease on going from the TPMA to the TPMA*3 system translates into an expected $\Delta G_{\text {OMRP }}$ increase of ca. $4.1 \mathrm{kcal} / \mathrm{mol}$ under the assumption of constant "carbophilicity". This is in rather good agreement with the calculated $\Delta G_{\text {OMRP }}$ increase of $2.8 \mathrm{kcal} / \mathrm{mol}$.

\section{Discussion}

Kinetically, a steady-state radical concentration should be defined by the balance of the rates of radical generation and termination, as shown by Eq 7, assuming that termination is a bimolecular reaction between $\mathrm{Cu}^{\mathrm{II}}$ - $\mathrm{R}$ organometallic species and propagating radicals. Furthermore, the molecular weights should be defined by the ratio between the propagation and termination rates, as shown in Eq 8.

$$
\begin{aligned}
& {[R \cdot]=\frac{f k_{a z o}[A I B N]}{k_{t C u(I I)}\left[L / C u^{I I}-R\right]}} \\
& D P=\frac{M_{n}}{M W_{n B A}}=\frac{\text { Rate }_{p}}{\text { Rate } C R T_{C R}}=\frac{k_{p}[M][R \cdot]}{k_{t C u(I I)}\left[C u^{I I}-R\right][R \cdot]}=\frac{k_{p}[M]}{k_{t C u(I I)}\left[C u^{I I}-R\right]}
\end{aligned}
$$

CRT should dominate relative to conventional (non-catalyzed) radical termination and therefore the latter can be neglected, due to the large amounts of $\mathrm{L} / \mathrm{Cu}^{\mathrm{I}}$ used. Until more kinetic data are available on the specific rates of addition, dissociation and termination (Scheme 3), only overall rate coefficients of CRT, $k_{C R T}^{a p p}$, can be estimated. Thus taking $k_{C R T}^{a p p}=\mathrm{k}_{\mathrm{tCu}(\mathrm{II})}\left[\mathrm{Cu} \mathrm{Cu}^{\mathrm{II}} \mathrm{R}\right], \mathrm{Eq} 7 \& 8$ can be rearranged to give Eq 9 \& 10, which were used to calculate apparent rate coefficients of $\mathrm{Cu}$-mediated termination, as summarized in Table 3.

$k_{C R T}^{a p p}=\frac{f k_{a z o}[A I B N]}{[R \cdot]}$ 
$k_{C R T}^{a p p}=\frac{k_{p}[M]}{[D P]}$

Average values of $k_{C R T}^{a p p}$ from eq. 9 and 10 were calculated at $\mathrm{L} / \mathrm{Cu}^{\mathrm{I}}$ loading of $500 \mathrm{ppm}\left(\left[\mathrm{L} / \mathrm{Cu}^{\mathrm{l}}\right]_{0}=1.74 \mathrm{mM}\right)$. The redox potentials, values of KомrP and values of KатRP are also presented in Table 3, in order to gain insight into the relationship between catalyst structure and reactivity.

Table 3. Values of $\mathrm{E}_{1 / 2}\left(\mathrm{mV}\right.$ vs. SCE) and calculated BDE (kcal/mol) of the $\mathrm{Cu}^{\mathrm{II}}-\mathrm{R}$ bond for $\mathrm{MBrP}$ in $\mathrm{MeCN}$ at $25^{\circ} \mathrm{C}$. Estimated overall rate coefficients of $\mathrm{CRT}, k_{C R T}^{a p p}\left(\mathrm{M}^{-1} \mathrm{~s}^{-1}\right)$, from kinetics and molecular weight data are also included.

$\begin{array}{ccccc}\text { Ligand } & \mathbf{E}_{1 / 2} & \text { KoMRP }^{c} & \text { KATRP } & {\text { Average } k_{C R T}^{a p p}}^{f} \\ \text { BPMA }^{\text {Me }} & 174^{\mathrm{a}} & 5.6 \times 10^{6} & 7.3 \times 10^{-10 \mathrm{~d}} & 1.2 \times 10^{1} \\ \text { BPMA }^{* \operatorname{Pr}} & 70^{\mathrm{a}} & 8.3 \times 10^{7} & 4.7 \times 10^{-8 \mathrm{~d}} & 2.0 \times 10^{1} \\ \text { TPMA }^{2} & 22^{\mathrm{b}} & 5.3 \times 10^{8} & 3.2 \times 10^{-7 \mathrm{e}} & 2.9 \times 10^{1} \\ \text { TPMA }^{* 1} & -69^{\mathrm{b}} & 3.4 \times 10^{9} & 5.9 \times 10^{-6 \mathrm{~d}} & 4.5 \times 10^{1} \\ \text { TPMA }^{* 2} & -133^{\mathrm{b}} & 6.7 \times 10^{9} & 1.5 \times 10^{-4 \mathrm{~d}} & 5.5 \times 10^{1} \\ \text { TPMA }^{* 3} & -177^{\mathrm{b}} & 6.0 \times 10^{10} & 4.2 \times 10^{-4 \mathrm{e}} & 9.6 \times 10^{1}\end{array}$

a This work. b From ref. ${ }^{11}$. ${ }^{c}$ Calculated from $\Delta$ GomRP in Table $2 \mathrm{~d}$ Estimated from the $\beta^{\mathrm{II}} / \beta^{\mathrm{I}}$ ratio (see text below) obtained from electrochemistry according to a modified version of the Nernst equation presenting in Ref 66. e Calculated.12 f Averaged value of $k_{C R T}^{a p p}$ estimated from kinetics (Eq 9) and molecular weight data (Eq 10) at 500 ppm $[\mathrm{Cu}]_{0}$.

Table 3 shows that the more reducing the $\mathrm{L} / \mathrm{Cu}^{\mathrm{I}}$ complexes have larger values of Komrp. Indeed, $\mathrm{Cu}^{\mathrm{II}}$ species with more negative reduction potential should be relatively more stable. This is also the reason for the increase in KATRP for more active catalysts. Also, the rate of $\mathrm{Cu}$-mediated termination increases with more ATRP active catalysts. Interestingly, the magnitude by which these three parameters are affected by the redox potential is dramatically different. It has been reported that $\ln K_{\text {ATRP }}$ increases linearly with the reduction potential with an overall increase by 6 orders of magnitude for the six complexes studied. On the other hand, KomRP should increase only by four orders of magnitude, according to the DFT calculations. However, the 
apparent rate coefficients of CRT, $k_{C R T}^{a p p}$, increased only by one order of magnitude. Thus, termination is less sensitive to the electronic properties of the $\mathrm{L} / \mathrm{Cu}^{\mathrm{I}}$ complex than the two K parameters. It is worthy to note that although the calculated values of KомRP at room temperature are large, the fraction of $\mathrm{Cu}^{\mathrm{II}}-\mathrm{R}$ relative to total copper should be small (for BPMA and TPMA systems), due to the small concentration of radicals $\left(\left[\mathrm{R}^{\bullet}\right] \sim 1 \times 10^{-9} \mathrm{M}\right)$. This fraction should further decrease upon increasing temperatures due to a decrease in KomRP. A comparison of the overall rates of $\mathrm{Cu}$ mediated termination with KoMRP and $\mathrm{K}_{\mathrm{ATRP}}$ with respect to redox potential is shown in Figure 6.

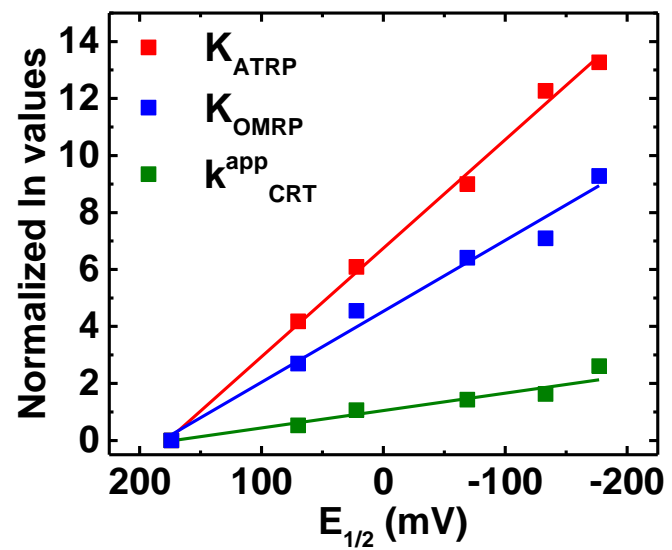

Figure 6. Relationship between reduction potential and $\mathrm{K}_{\text {ATRP }}$ (red) for MBrP in $\mathrm{MeCN}$ at $25^{\circ} \mathrm{C}$, KomRp for acrylate radical (blue) and apparent rate coefficient of $\mathrm{Cu}$ mediated termination, $k_{C R T}^{a p p}$ (green). The y-axis values were arbitrarily scaled to zero for the $\mathrm{BPMA}^{\mathrm{Me}}$ system $\left(\mathrm{E}_{1 / 2}=174 \mathrm{mV}\right)$ after natural $\ln$ were taken in order to emphasize the relative slopes of the three parameters.

All of the data presented in this study are consistent with the formation of a $\mathrm{L} / \mathrm{Cu}^{\mathrm{II}}-\mathrm{R}$ intermediate which reacts with another radical, resulting in termination. However, as alluded to above, the formation of the $\mathrm{L} / \mathrm{Cu}^{\mathrm{II}}-\mathrm{R}$ intermediate does not imply that termination must happen, i.e. the trapping process could be reversible. Recent experiments showed that dissociation of $\mathrm{L} / \mathrm{Cu}^{\mathrm{II}}-\mathrm{R}$ may be fast at temperatures above $0^{\circ} \mathrm{C} .47$ 
According to Eq 7 \& 8, the rates of polymerization and molecular weights should scale as $1 / \mathrm{k}_{\mathrm{tCu}(\mathrm{III}}\left[\mathrm{L} / \mathrm{Cu}^{\mathrm{II}}-\mathrm{R}\right]$ but, due to the intermediacy of the organometallic species, its concentration at this stage can only be estimated by DFT calculations. As shown in Scheme 3, two limiting scenarios can be envisaged; one in which the OMRP equilibrium is established and one in which it is not. The establishment of the OMRP equilibrium depends on whether the $\mathrm{L} / \mathrm{Cu}^{\mathrm{II}}-\mathrm{R}$ species is able to dissociate back to the radical and $\mathrm{L} / \mathrm{Cu}^{\mathrm{I}}$ before the complex undergoes CRT with a second radical. If equilibrium cannot be established because of fast termination, the rate limiting step may be the addition of a radical to $\mathrm{L} / \mathrm{Cu}^{\mathrm{I}}$, followed by a fast reaction of $\mathrm{L} / \mathrm{Cu}^{\mathrm{II}}-\mathrm{R}$ with growing radicals. Conversely, when the equilibrium can be established, the termination of a second radical with $\mathrm{L} / \mathrm{Cu}^{\mathrm{II}}-\mathrm{R}$, leading to $\mathrm{CRT}$, becomes the rate determining step. Under these conditions, the radical concentration (rate of polymerization) and molecular weights will be differently defined, by two limiting expressions presented in Eq 11-14, as derived in the Supporting Information.

If, $\mathrm{k}_{\mathrm{tCu}(\mathrm{II})}\left[\mathrm{R}^{\bullet}\right]>>\mathrm{k}_{\mathrm{dis}}$

$$
\begin{aligned}
& D P=\frac{M_{n}}{M W_{n B A}}=\frac{k_{p}[M]}{k_{a d d}\left[L / C u^{I}\right]} \\
& {[R \cdot]=\frac{f k_{a z o}[A I B N]}{k_{a d d}\left[L / C u^{I}\right]}}
\end{aligned}
$$

If, $\mathrm{k}_{\text {dis }}>>\mathrm{ktCu}(\mathrm{II})\left[\mathrm{R}^{\bullet}\right]$

$$
\begin{aligned}
& D P=\frac{M_{n}}{M W_{n B A}}=\frac{k_{p}[M]}{k_{t C u(I I)}\left[L / C u^{I}\right][R \cdot] K_{O M R P}} \\
& {[R \cdot]=\sqrt{\frac{f k_{a z o}[A I B N]}{k_{t C u(I I)}\left[L / C u^{I}\right] K_{O M R P}}}}
\end{aligned}
$$

In the case of $\mathrm{ktCu}(I)_{\mathrm{II}}\left[\mathrm{R}^{\bullet}\right]>>\mathrm{kdis}$, both rate of polymerization and molecular weights will scale inversely with $\left[\mathrm{L} / \mathrm{Cu}^{\mathrm{I}}\right]$. However, for the scenario in which $\mathrm{k}_{\mathrm{dis}}>>\mathrm{k}_{\mathrm{tCu}}(\mathrm{III})\left[\mathrm{R}^{\bullet}\right]$,

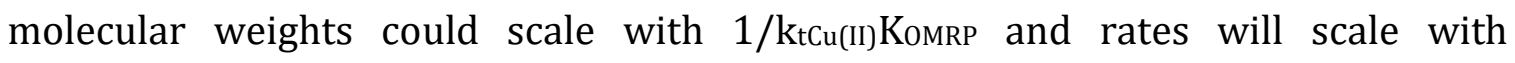
$1 /\left(k_{t C u(I I)} K_{O M R P}\left[L / C u^{I}\right]\right)^{1 / 2}$. Indeed, when $\left[\mathrm{L} / \mathrm{Cu}^{I}\right] 0$ was increased 10 times, the 
molecular weights obtained in the presence of $\mathrm{BPMA}^{* \mathrm{Pr}} / \mathrm{Cu}^{\mathrm{I}}$, (Figure 4) decreased by a factor of 10 but only by a factor of 1.4 for TPMA/CuI. This indicates that these two complexes operate under two different kinetic regimes. This suggests that BPMA*Pr /Cu' undergoes faster CRT relative to dissociation, with MW defined by Eq 11. On the other hand, for the TPMA/ $\mathrm{Cu}^{\mathrm{I}}$ system, an OMRP equilibrium can be established and therefore the molecular weights should follow Eq 13. Hence, increasing $[\mathrm{L} / \mathrm{Cu}]_{0}$ will produce more $\mathrm{L} / \mathrm{Cu}^{\mathrm{II}}-\mathrm{R}$ but the $\left[\mathrm{L} / \mathrm{Cu}^{1}\right]\left[\mathrm{R}^{*}\right]$ product could stay approximately constant, effectively showing little dependence of the molecular weight on $\left[\mathrm{L} / \mathrm{Cu}^{\mathrm{I}}\right]_{0}$. For all systems, increasing $\left[\mathrm{L} / \mathrm{Cu}^{\mathrm{I}}\right]_{0}$ showed a decrease in rate of polymerization since rates will scale with either $1 /\left[\mathrm{L} / \mathrm{Cu}^{\mathrm{I}}\right]$ or $1 /\left[\mathrm{L} / \mathrm{Cu}^{\mathrm{I}}\right]^{1 / 2}$.

It was recently proposed that CRT may proceed by radical coupling via a $\mathrm{L} / \mathrm{Cu}^{\mathrm{III}} \mathrm{R}_{2}$ intermediate ${ }^{24}$ The $\left[\mathrm{Cu}^{\mathrm{II}}\left(\mathrm{BPMA}^{* \mathrm{Pr}}\right)(\mathrm{R})\right]$ complex has a weakly coordinated $\mathrm{MeCN}$ ligand which decreases the steric hindrance at the $\mathrm{Cu}^{\mathrm{II}}-\mathrm{R}$ bond. This makes the complex more susceptible to accept a second incoming radical, as shown in the top of Scheme 5. On the other hand, for the $\left[\mathrm{Cu}^{\mathrm{II}}(\mathrm{TPMA})(\mathrm{R})\right]$ complex to accept another radical, ligand rearrangement (arm opening) may be necessary and this would effectively slow down the CRT process, as shown in the bottom of Scheme 5. The termination in this case may also proceed by the direct reaction of a $\mathrm{L} / \mathrm{Cu}^{\mathrm{II}}-\mathrm{R}$ complex with an incoming radical by $\mathrm{H}$-abstraction or addition to the metal bonded chain. 


\section{Scenario 1: $[\mathbf{R} \cdot] \mathbf{k}_{\mathrm{tCu}(\mathrm{II})}>\mathbf{k}_{\mathrm{dis}}$}
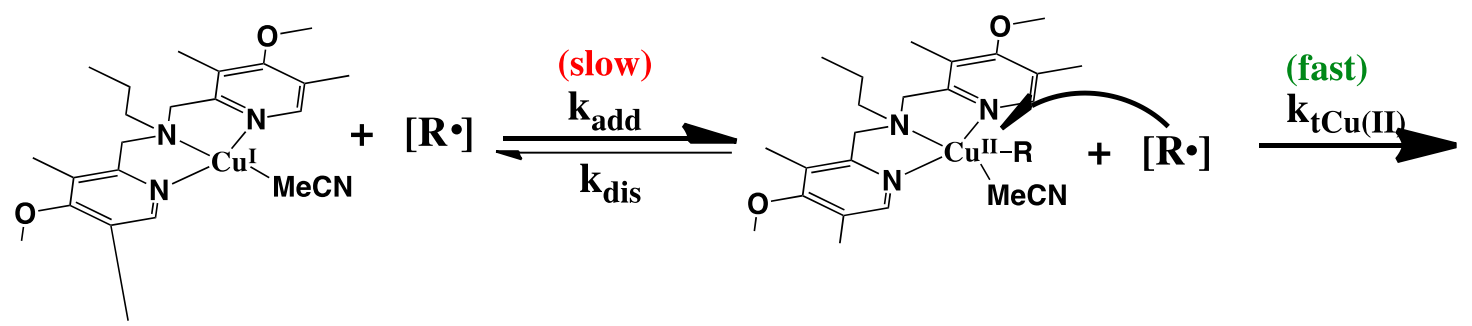

\section{Scenario 2: $\mathbf{k}_{\mathbf{d i s}}>[\mathbf{R}] \mathbf{k}_{\mathrm{tCu}(\mathrm{II})}$}
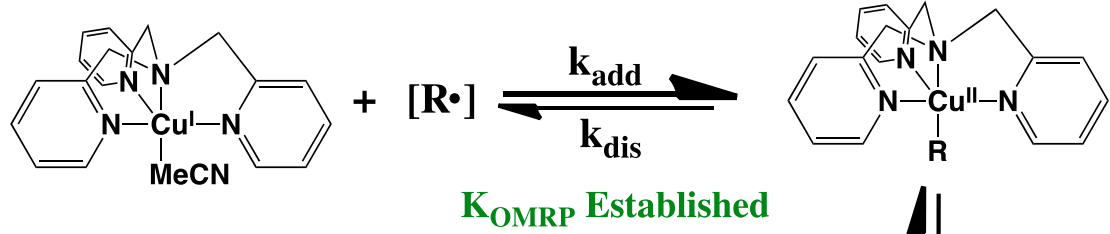

$+[\mathbf{R}$

(slow)

K OMRP Established

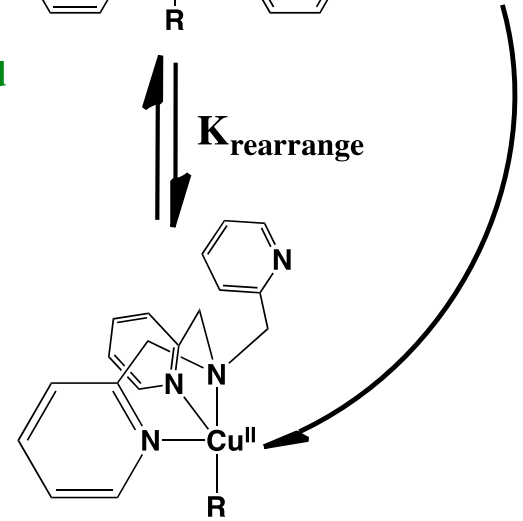

Scheme 5. Two possible scenarios in which the OMRP equilibrium is not established (top) and one in which it is (bottom). Arrow thickness corresponds to relative rates. For each scenarios, the radical in the second step may attack either the $\beta-\mathrm{H}$ atom, the metal-bonded $\mathrm{C}$ atom or the metal, according to pathways (b), (c) and (d) in Scheme 2 , respectively.

When analyzing the results related to the geometrically similar TPMA*n family of ligands (Figure 1), the more reducing $\mathrm{L} / \mathrm{Cu}^{\mathrm{I}}$ complexes yields both a slower rate of polymerization and lower molecular weights, as shown in Figure 3. At the same $\left[\mathrm{Cu}^{\mathrm{I}}\right]_{0}$ $=500 \mathrm{ppm}$, the measured molecular weights are $\sim 40,32,21$, and $13 \times 10^{4}$ for TPMA, TPMA $^{* 1}$, TPMA $^{* 2}$ and TPMA*3, respectively. These systems, structurally similar to the parent TPMA system, may also operate according to scenario 2, (bottom of Scheme 5 and Eq's 13 \& 14), hence the molecular weights should depend on $1 / \mathrm{k}_{\mathrm{tCu}}(\mathrm{II})$ 
$\left[\mathrm{Cu}^{\mathrm{I}}\right]\left[\mathrm{R}^{\bullet}\right] \mathrm{KomRP}$ with rates depending on $1 /\left(\mathrm{ktCu}(\mathrm{II})\left[\mathrm{L} / \mathrm{Cu}^{\mathrm{I}}\right] \mathrm{KomRP}^{1 / 2}\right.$. As shown in Table 3 , KomRP increases moving from TPMA to TPMA*3 which would explain the lower

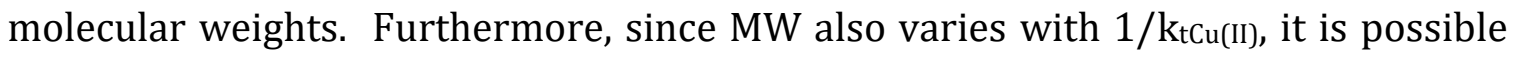
that the observed molecular weight decrease is due to a change both in KomRP and ktcu(II)..

The termination in ATRP of acrylates can proceeds by either coupling or disproportionation. There is a debate in recent reports if the preference for disproportionation (supported by computations) can originate from tertiary radicals formed by backbiting. ${ }^{48-49}$ In the presence of $\mathrm{L} / \mathrm{Cu}^{1}$ or $\mathrm{Cu}^{0}$, experiments show preference for disproportionation-like or coupling-like products, depending on reaction conditions and ligands. ${ }^{18,24}$ To better understand the mechanism of $\mathrm{Cu}$ induced CRT, it is important to understand the termination mechanism of acrylate radicals. Thus, our future efforts will focus on further probing the CRT mechanism via a combination of experimental and computational work.

\section{Conclusions}

A new, electron rich tridentate ligand, $\mathrm{BPMA}^{* \operatorname{Pr}}$ was synthesized and compared with the less electron-rich BPMAMe ligand and with several tetradentate TPMA $^{* n}$ ( $n=0-3$ ligands). The complexes were characterized by cyclic-voltammetry, UV-Vis and X-ray diffraction. $\mathrm{L} / \mathrm{Cu}^{\mathrm{I}}$ complexes were formed in situ and studied as CRT catalysts in the polymerization of n-butyl acrylate. The complexes with more negative redox potentials and higher ATRP activity show higher activity in CRT, while the ligand denticity (tridentate $v s$. tetradentate) may determine the rate limiting step of CRT. The effect of $\mathrm{E}_{1 / 2}$ of $\mathrm{Cu}$ complexes on $\mathrm{K}_{\mathrm{ATRP}}$ is larger than on $k_{C R T}^{a p p}$. The calculated KoмRP values correlate well with the apparent rates of CRT. The molecular weight and kinetic analyses show that two different kinetic regimes are possible, depending on the relative rates of dissociation of the OMRP dormant species vs. its reaction with a second radical. If $\mathrm{k}_{\mathrm{tCu}(\mathrm{II})}\left[\mathrm{R}^{*}\right]>\mathrm{k}_{\mathrm{dis}}$, then the rate of termination depends on $k_{\text {add }}\left[\mathrm{Cu}^{\mathrm{I}}\right]\left[\mathrm{R}^{*}\right]$ and molecular weights decrease for larger values of $[\mathrm{L} / \mathrm{Cu}] \mathrm{C}^{\mathrm{I}}$. 
However, if $\mathrm{kdis}_{\mathrm{is}}>\mathrm{ktCu(II)}\left[\mathrm{R}^{\bullet}\right]$, then the OMRP equilibrium can be established and the rate of termination depends on $\mathrm{k}_{\mathrm{tCu}(\mathrm{CI})} \mathrm{K}_{\mathrm{OMRP}}$ and molecular weights do not depend on $\left[\mathrm{L} / \mathrm{Cu}^{\mathrm{I}}\right]$. The details of the intimate mechanism leading from the $\mathrm{L} / \mathrm{Cu}^{\mathrm{II}} \mathrm{R}$ species to the regeneration of the $\mathrm{L} / \mathrm{Cu}^{\mathrm{I}}$ catalyst and the terminated chains, however, remain elusive. Additional investigations aimed at clarifying these details are in progress and will be reported in due course.

\section{Associated Content}

Details of experimental procedures, additional characterization data, X-ray crystallographic data and model polymerization results. This material is available free of charge via the Internet at http://pubs.acs.org

\section{Author Information}

\section{Corresponding Authors}

Rinaldo.Poli@lcc-toulouse.fr

Km3b@andrew.cmu.edu

Notes

The authors declare no competing financial interest.

\section{Acknowledgements}

We thank the Centre National de la Recherche Scientifique (CNRS) for support through the PICS06782 grant. This work was granted access to the HPC resources of CINES and IDRIS under the allocation (2006 through 2015)-086343 made by GENCI (Grand Equipement National de Calcul Intensif) and to the resources of the CICT (Centre Interuniversitaire de Calcul de Toulouse, project CALMIP). We are also grateful to the French Embassy in Washington D.C. for a Chateaubriand Fellowship to TR. KM acknowledges support from the NSF (CHE 1400052). Pawel Krys is acknowledged for fruitful discussions and suggestions.

\section{References}


1. Matyjaszewski, K.; Xia, J., Atom Transfer Radical Polymerization. Chem. Rev. 2001, 101 (9), 2921-2990.

2. Tang, W.; Nanda, A. K.; Matyjaszewski, K., Effect of [pyridylmethanimine]/[CuI] ratio, ligand, solvent and temperature on the activation rate constants in atom transfer radical polymerization. Macromol. Chem. Phys. 2005, 206 (12), 1171-1177.

3. Tang, W.; Matyjaszewski, K., Effect of Ligand Structure on Activation Rate Constants in ATRP. Macromolecules 2006, 39 (15), 4953-4959.

4. Tang, W.; Tsarevsky, N. V.; Matyjaszewski, K., Determination of Equilibrium Constants for Atom Transfer Radical Polymerization. J. Am. Chem. Soc. 2006, 128 (5), 1598-1604.

5. $\quad$ Tsarevsky, N. V.; Braunecker, W. A.; Tang, W.; Brooks, S. J.; Matyjaszewski, K.; Weisman, G. R.; Wong, E. H., Copper-based ATRP catalysts of very high activity derived from dimethyl cross-bridged cyclam. J. Mol. Catal. A: Chem. 2006, 257 (1-2), 132-140. 6. Tsarevsky, N. V.; Tang, W.; Brooks, S. J.; Matyjaszewski, K., Factors determining the performance of copper-based atom transfer radical polymerization catalysts and criteria for rational catalyst selection. ACS Symp. Ser. 2006, 944 (Controlled/Living Radical Polymerization), 56-70.

7. Tang, W.; Kwak, Y.; Tsarevsky, N. V.; Matyjaszewski, K., Effect of ligand and initiator structures on the equilibrium constants in ATRP. Polym. Prepr. (Am. Chem. Soc., Div. Polym. Chem.) 2007, 48 (1), 392-393.

8. Tang, W.; Matyjaszewski, K., Effects of Initiator Structure on Activation Rate Constants in ATRP. Macromolecules 2007, 40 (6), 1858-1863.

9. Tang, W.; Kwak, Y.; Braunecker, W.; Tsarevsky, N. V.; Coote, M. L.; Matyjaszewski, K., Understanding Atom Transfer Radical Polymerization: Effect of Ligand and Initiator Structures on the Equilibrium Constants. J. Am. Chem. Soc. 2008, 130 (32), 10702-10713.

10. Tsarevsky, N. V.; Braunecker, W. A.; Tang, W.; Matyjaszewski, K., The atom transfer radical polymerization equilibrium: structural and medium effects. ACS Symp. Ser. 2009, 1023 (Controlled/Living Radical Polymerization: Progress in ATRP), 85-96.

11. Kaur, A.; Ribelli, T. G.; Schroder, K.; Matyjaszewski, K.; Pintauer, T., Properties and ATRP Activity of Copper Complexes with Substituted Tris(2pyridylmethyl)amine-Based Ligands. Inorganic Chemistry 2015, 54 (4), 1474-1486.

12. Schroder, K.; Mathers, R. T.; Buback, J.; Konkolewicz, D.; Magenau, A. J. D.; Matyjaszewski, K., Substituted Tris(2-pyridylmethyl)amine Ligands for Highly Active ATRP Catalysts. ACS Macro Letters 2012, 1 (8), 1037-1040.

13. Navon, N.; Cohen, H.; Meyerstein, D., Effect of Stabilizing Ligands on the Rate of Reaction of CuIL with CCl3CO2- in Aqueous Solutions. 1. L = HOOCCHCHCOO. Inorganic Chemistry 1997, 36 (17), 3781-3783.

14. Navon, N.; Golub, G.; Cohen, H.; Meyerstein, D., Kinetics and Reaction Mechanisms of Copper(I) Complexes with Aliphatic Free Radicals in Aqueous Solutions. A Pulse-Radiolysis Study. Organometallics 1995, 14 (12), 5670-5676. 
15. Allan, L. E. N.; Perry, M. R.; Shaver, M. P., Organometallic mediated radical polymerization. Prog. Polym. Sci. 2012, 37 (1), 127-156.

16. Poli, R., Radical Coordination Chemistry and Its Relevance to Metal-Mediated Radical Polymerization. Eur. J. Inorg. Chem. 2011, 2011 (10), 1513-1530.

17. Hurtgen, M.; Detrembleur, C.; Jerome, C.; Debuigne, A., Insight into Organometallic-Mediated Radical Polymerization. Polymer Reviews 2011, 51 (2), 188-213.

18. Wang, Y.; Soerensen, N.; Zhong, M.; Schroeder, H.; Buback, M.; Matyjaszewski, $\mathrm{K}$. Improving the "Livingness" of ATRP by Reducing $\mathrm{Cu}$ Catalyst Concentration. Macromolecules 2013, 46 (3), 683-691.

19. Schroder, K.; Konkolewicz, D.; Poli, R.; Matyjaszewski, K., Formation and Possible Reactions of Organometallic Intermediates with Active Copper(I) Catalysts in ATRP. Organometallics 2012, 31 (22), 7994-7999.

20. Matyjaszewski, K.; Woodworth, B. E., Interaction of Propagating Radicals with Copper(I) and Copper(II) Species. Macromolecules 1998, 31 (15), 4718-4723.

21. Ribelli, T. G.; Konkolewicz, D.; Pan, X.; Matyjaszewski, K., Contribution of Photochemistry to Activator Regeneration in ATRP. Macromolecules 2014, 47 (18), 6316-6321.

22. Ribelli, T. G.; Konkolewicz, D.; Bernhard, S.; Matyjaszewski, K., How are Radicals (Re)Generated in Photochemical ATRP? J. Am. Chem. Soc. 2014, 136 (38), 13303-13312.

23. Buback, M.; Egorov, M.; Gilbert, R. G.; Kaminsky, V.; Olaj, O. F.; Russell, G. T.; Vana, P.; Zifferer, G., Critically Evaluated Termination Rate Coefficients for FreeRadical Polymerization, 1. The Current Situation. Macromol. Chem. Phys. 2002, 203 (18), 2570-2582.

24. Nakamura, Y.; Ogihara, T.; Yamago, S., Mechanism of $\mathrm{Cu}(\mathrm{I}) / \mathrm{Cu}(0)$-Mediated Reductive Coupling Reactions of Bromine-Terminated Polyacrylates, Polymethacrylates, and Polystyrene. ACS Macro Letters 2016, 5 (2), 248-252.

25. Wahidur Rahaman, S. M.; Matyjaszewski, K.; Poli, R., Cobalt(III) and copper(II) hydrides at the crossroad of catalysed chain transfer and catalysed radical termination: a DFT study. Polymer Chemistry 2016, 7 (5), 1079-1087.

26. Wayland, B. B.; Fu, X.; Peng, C.-H.; Lu, Z.; Fryd, M., Living radical polymerizations mediated by metallo-radical and organo-transition metal complexes. ACS Symp. Ser. 2006, 944 (Controlled/Living Radical Polymerization), 358-371.

27. Wayland, B. B.; Peng, C.-H.; Fu, X.; Lu, Z.; Fryd, M., Degenerative Transfer and Reversible Termination Mechanisms for Living Radical Polymerizations Mediated by Cobalt Porphyrins. Macromolecules 2006, 39 (24), 8219-8222.

28. Wang, F.-S.; Yang, T.-Y.; Hsu, C.-C.; Chen, Y.-J.; Li, M.-H.; Hsu, Y.-J.; Chuang, M.C.; Peng, C.-H., The Mechanism and Thermodynamic Studies of CMRP: Different Control Mechanisms Demonstrated by CoII(TMP), CoII(salen*), and CoII(acac)2 Mediated Polymerization, and the Correlation of Reduction Potential, Equilibrium Constant, and Control Mechanism. Macromol. Chem. Phys. 2016, 217 (3), 422-432.

29. Debuigne, A.; Poli, R.; Jérôme, C.; Jérôme, R.; Detrembleur, C., Overview of cobalt-mediated radical polymerization: Roots, state of the art and future prospects. Prog. Polym. Sci. 2009, 34 (3), 211-239. 
30. Kinoshita, I.; James Wright, L.; Kubo, S.; Kimura, K.; Sakata, A.; Yano, T.; Miyamoto, R.; Nishioka, T.; Isobe, K., Design and synthesis of copper complexes of novel ligands based on the pyridine thiolate group. Dalton Transactions 2003, (10), 1993-2003.

31. Tehranchi, J.; Donoghue, P. J.; Cramer, C. J.; Tolman, W. B., Reactivity of (Dicarboxamide)MII-OH (M = Cu, Ni) Complexes - Reaction with Acetonitrile to Yield MII-Cyanomethides. Eur. J. Inorg. Chem. 2013, 2013 (22-23), 4077-4084.

32. Grzegorzek, N.; Pawlicki, M.; Szterenberg, L.; Latos-Grażyński, L., Organocopper(II) Complex of 21-Diphenylphosphoryl-Carbaporpholactone Hybrid: A Side-On Coordination Mode of Copper(II). J. Am. Chem. Soc. 2009, 131 (21), 72247225.

33. Hu, X.; Castro-Rodriguez, I.; Meyer, K., Copper Complexes of NitrogenAnchored Tripodal N-Heterocyclic Carbene Ligands. J. Am. Chem. Soc. 2003, 125 (40), 12237-12245.

34. Pawlicki, M.; Kańska, I.; Latos-Grażyński, L., Copper(II) and Copper(III) Complexes of Pyrrole-Appended Oxacarbaporphyrin. Inorganic Chemistry 2007, 46 (16), 6575-6584.

35. Jastrzbski, J. T. B. H., van Koten, G., Structures and Reactivities of Organocopper Compounds in Modern Organocopper Chemistry; Wiley-VCH: Weinheim, 2002.

36. Suess, A. M.; Ertem, M. Z.; Cramer, C. J.; Stahl, S. S., Divergence between Organometallic and Single-Electron-Transfer Mechanisms in Copper(II)-Mediated Aerobic C-H Oxidation. J. Am. Chem. Soc. 2013, 135 (26), 9797-9804.

37. Ziegler, M. S.; Levine, D. S.; Lakshmi, K. V.; Tilley, T. D., Aryl Group Transfer from Tetraarylborato Anions to an Electrophilic Dicopper(I) Center and MixedValence $\mu$-Aryl Dicopper(I,II) Complexes. J. Am. Chem. Soc. 2016, 138 (20), 64846491.

38. Neuville, L., Alternative and Emerging Reagents for the Arylation of Heteronucleophiles. In Copper-Mediated Cross-Coupling Reactions, John Wiley \& Sons, Inc.: 2013; pp 113-185.

39. Chemler, S. R., Evolution of copper(II) as a new alkene amination promoter and catalyst. J. Organomet. Chem. 2011, 696 (1), 150-158.

40. Ribas, X.; Calle, C.; Poater, A.; Casitas, A.; Gómez, L.; Xifra, R.; Parella, T.; BenetBuchholz, J.; Schweiger, A.; Mitrikas, G.; Solà, M.; Llobet, A.; Stack, T. D. P., Facile C-H Bond Cleavage via a Proton-Coupled Electron Transfer Involving a C-H...CuII Interaction. J. Am. Chem. Soc. 2010, 132 (35), 12299-12306.

41. Zhang, H.; Yao, B.; Zhao, L.; Wang, D.-X.; Xu, B.-Q.; Wang, M.-X., Direct Synthesis of High-Valent Aryl-Cu(II) and Aryl-Cu(III) Compounds: Mechanistic Insight into Arene C-H Bond Metalation. J. Am. Chem. Soc. 2014, 136 (17), 6326-6332.

42. Luo, J.; Rath, N. P.; Mirica, L. M., Dinuclear Co(II)Co(III) Mixed-Valence and Co(III)Co(III) Complexes with N- and O-Donor Ligands: Characterization and Water Oxidation Studies. Inorganic Chemistry 2011, 50 (13), 6152-6157.

43. Astner, J.; Weitzer, M.; Foxon, S. P.; Schindler, S.; Heinemann, F. W.; Mukherjee, J.; Gupta, R.; Mahadevan, V.; Mukherjee, R., Syntheses, characterization, and reactivity of copper complexes with tridentate N-donor ligands. Inorg. Chim. Acta 2008, 361 (1), 279-292. 
44. Pintauer, T., Tris(2-pyridylmethyl)amine based ligands in copper catalyzed atom transfer radical addition (ATRA) and polymerization (ATRP). ACS Symp. Ser. 2015, 1187 (Controlled Radical Polymerization), 105-128.

45. Eckenhoff, W. T.; Pintauer, T., Structural Comparison of Copper(I) and Copper(II) Complexes with Tris(2-pyridylmethyl)amine Ligand. Inorganic Chemistry 2010, 49 (22), 10617-10626.

46. Eckenhoff, W. T.; Pintauer, T., Atom Transfer Radical Addition in the Presence of Catalytic Amounts of Copper(I/II) Complexes with Tris(2-pyridylmethyl)amine. Inorganic Chemistry 2007, 46 (15), 5844-5846.

47. Soerensen, N.; Schroeder, H.; Buback, M., SP-PLP-EPR Measurement of CuIIMediated ATRP Deactivation and CuI-Mediated Organometallic Reactions in Butyl Acrylate Polymerization. Macromolecules 2016, 49 (13), 4732-4738.

48. Nakamura, Y.; Lee, R.; Coote, M. L.; Yamago, S., Termination Mechanism of the Radical Polymerization of Acrylates. Macromol. Rapid Commun. 2016, 37 (6), 506513.

49. Ballard, N.; Hamzehlou, S.; Ruipérez, F.; Asua, J. M., On the Termination Mechanism in the Radical Polymerization of Acrylates. Macromol. Rapid Commun. 2016, 37 (16), 1364-1368. 


\section{For Table of Content Use Only}

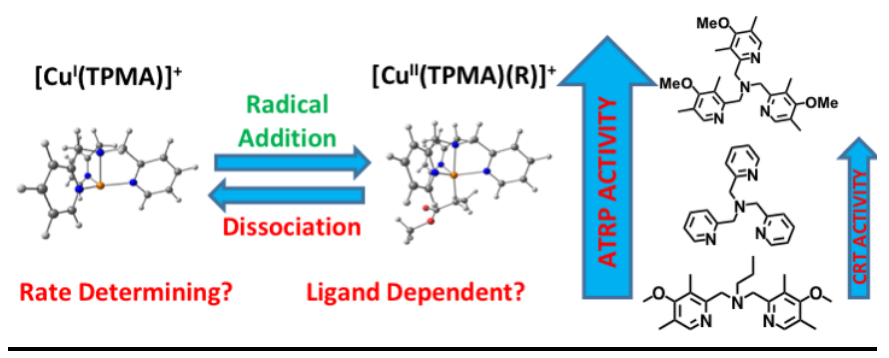

